Edited by S E Shumway, University of

Connecticut and G E Rodrick, University of

Florida, USA

Woodhead Publishing Series in Food Science,

Technology and Nutrition No. 167

(C) 2009 Woodhead Publishing Limited

\title{
Viral contaminants of molluscan shellfish: detection and characterisation
}

\author{
Albert Bosch ${ }^{1}$, Rosa M. Pintó ${ }^{1}$, Françoise S. Le Guyader², \\ ${ }^{1}$ Enteric Virus Laboratory, Department of Microbiology, University of Barcelona, Spain \\ ${ }^{2}$ Laboratoire de Microbiologie, IFREMER, Nantes ${ }_{1}$ France
}




\section{Introduction: human enteric viruses and their fate in the environment}

A wide variety of different viruses, representing the majority of the families of animal viruses, can be present in human and animal faecal wastes and urine. Especially important are a variety of non-enveloped human and animal enteric pathogenic viruses that can enter the environment through the discharge of waste materials from infected individuals; contaminate food products, and drinking and recreational waters; and be transmitted back to susceptible individuals to continue the cycle of infection. These enteric viruses cause a wide spectrum of illnesses in man including hepatitis, gastroenteritis, meningitis, fever, rash, conjunctivitis, and may be diabetes or SARS (Table 1). It is estimated that billions of cases of gastrointestinal illness occur annually worldwide (Parashar et al., 1998; Oh et al., 2003). A good deal of these diarrhoeal cases is to some extent the result of fecal contamination of the environment (Cabelli et al., 1983; Koopman et al., 1982; Fattal and Shuval, 1989; Moore et al., 1994, Pommepuy et al. 2005). In 1979, it was estimated that between 5 and 18 million people die every year from gastroenteritis. In the developing countries the burden of rotavirus disease in children under 5 years of age has been estimated to be over 125 million cases annually, of which 18 million are severe cases, and nearly half a million deaths in children under the age of 4 are attributable to rotavirus diarrhoea (Oh et al., 2003; Parashar et al., 1998). In the developed world, mortality due to rotavirus infection is very low; however, it remains an important cause of morbidity and of hospitalization in young children. Noroviruses (previously called Norwalk-like viruses), formerly included in the SRSV (small round structured viruses), account for over $90 \%$ of foodborne gastroenteritis affecting children and adults (Lopman et al., 2003, Blanton et al. 2006). Additionally, astroviruses were reported in 1996 to be second only to rotaviruses as a cause of hospitalization for childhood viral gastroenteritis (Glass et al., 1996), while adenoviruses and sapoviruses (previously called Sapporo-like viruses) have also been recognized as significant etiological agents of epidemic non-bacterial diarrhoea (Lopman et al., 2003). Poliomyelitis, caused by a picornavirus, was not too long ago the most feared viral disease; however the long pursued objective of its eradication seems presently at reach. Another picornavirus is the etiological agent of hepatitis A which accounts for around half the total number of hepatitis diagnosed worldwide, and some regions, as part of the Mediterranean region, are still endemic for hepatitis A (Pintó et al., 2006). Hepatitis $\mathrm{E}$ virus is the primary cause in tropical and subtropical developing countries of an enterically transmitted non-A non-B hepatitis, with a mortality rate of up to $20 \%$ in pregnant women (Lu et al. 2006; Reyes, 1993; Schlauder and Mushahwar, 2001).

Environmental Virology may be defined as the study of the extracellular behaviour of viruses which can be transmitted through various environments (water, sewage, soil, air or surfaces) or food, and persist enough in these vehicles to represent a health threat. As a scientific discipline, environmental virology was born after a large hepatitis outbreak occurred in New Delhi between December 1955 and January 1956. The origin of the outbreak, which was attributed to hepatitis $A$ at the time but now confirmed to be hepatitis $\mathrm{E}$, was the contamination by sewage, from one to six weeks prior to the epidemic, of Jumna River, the source of water for the treatment plant. Alum and chlorine treatment prevented bacterial infections, but 30,000 cases of hepatitis occurred among the population.

Enteric Viruses can be transmitted by a variety of routes, including direct and indirect contact, vector transmission, and vehicle transmission. Viruses are shed in extremely high numbers in the feces of infected individuals; patients suffering from diarrhoea or hepatitis may excrete from $10^{5}$ to $10^{11}$ virus particles per gram of stool (Farthing, 1989, Kageyama et al. 2003). Furthermore, a single episode of vomit of a patient with norovirus gastroenteritis may contain around $10^{7}$ particles (Cheesbrough et al., 1997). Ingestion of sewage contaminated water or food is the main route of infection with human enteric viruses, although the role of inanimate surfaces serving as vehicles for virus infection must 
not be underestimated. Viruses with a viraemic phase, such as the hepatitis viruses, may also be parenterally transmitted, although nowadays it is considered to be a much less frequent mode of transmission.

\section{Shellfishborne transmission of virus infections}

Despite indigenous marine virus strains outnumber any form of life in the sea, usually occurring in billion amounts per litre (Danovaro et al., 2001; Fuhrman, 1999), the only viral agents of public health concern in the marine environment are human viruses. Pathogenic viruses are routinely introduced into marine and estuarine waters through the discharge of treated and untreated sewage, since current water treatment practices are unable to provide virus-free wastewater effluents (Rao and Melnick, 1986).

The demands exerted by the expanding world population and industry make the marine environment increasingly susceptible to pollution from municipal sewage, industrial effluents and agricultural wastes. Seawater pollution control relies on secondary treatment of sewage and on the theoretically infinite dilution of wastes in the receiving waters. However, the marine environment, including oceans, has a finite ability to receive and recover from waste disposal practices, and certainly is incapable of unlimited waste assimilation. The type of treatment applied to human waste will ultimately determine the concentration of pathogens in treated sewage and sludge, and their relative risk of disposal. The maintenance and assessment of the virological quality and safety of marine water systems employed for recreating and seafood harvesting is of seminal importance in the prevention of diseases transmitted through the faecal-oral route, and may lead to significant reductions of economic losses due to the closures of tourists resorts and shellfish harvesting areas. For this reason, it is imperative to trace and characterize the type and origin of faecal contaminants in order to assess the associated health threat and the required corrective measures.

There are several routes by which viruses reach the sea, including direct discharge of treated or untreated sewage effluents, unintentional discharges by urban and rural run-off, waste input from boats, and via rivers when the discharges take place in fresh water. Mankind is exposed to enteric viruses in seawater mainly through the consumption of shellfish grown in contaminated waters, or to a lesser extend through recreational activities in sewage-polluted waters.

Several phenomena, such as flooding, treated and untreated polluted effluent discharges, or sewage runoff can elevate microbial contaminants in shellfish habitats, and, since bivalves are filter feeders, these molluscs can become reservoirs of human pathogens. Other types of seafood such as crabs (Goyal, 1984) or shrimps (Botero et al., 1996) can accumulate viruses on their shells and carnivorous shellfish, such as lobsters or crabs, can feed on contaminated bivalves (Hejkal and Gerba, 1981), but their role in the transmission of viral diseases is unproven.

Following the culinary tradition, bivalve shellfish is often consumed raw, like oysters and sometimes clams or cockles, or just lightly cooked, like most of other molluscs. This cooking habit, together with the fact that the whole animal including viscera is consumed, pose a major public health concern since shellfish act like passive carriers of human pathogenic viruses. Generally, commercial growth of shellfish species takes place in shallow, in-shore waters, which may receive occasional sewage pollution. The consumption of shellfish is very clearly linked to the transmission of enteric infections and epidemics have been recorded since medieval times in many countries (Lees, 2000). Although most of these outbreaks are caused by shellfish collected by unscrupulous professionals or careless private individuals, from areas where harvesting is prohibited, they also occur as a result of eating shellfish from authorized shellfish-producing areas, when these areas have been temporarily polluted (Mackowiak et al., 1976) and sanitary controls fail to provide a safe indication of viral pollution. 
Regardless of the variety of health-significant viruses found in shellfish, norovirus and hepatitis $A$ virus are the most relevant viral pathogens involved in shellfishborne diseases (Table 2). Norovirus infections represent the vast majority of shellfish-related outbreaks, and hepatitis $A$ is the most serious infectious disease caused by shellfish consumption. The United States Food and Drug Administration risk assessments estimate cases of norovirus gastroenteritis related to seafood consumption at some 100000 per year (Williams and Zorn, 1997), and epidemics of hepatitis A caused by food occur 10 times more often than those caused by water, being shellfish the cause of more than $50 \%$ of reported cases (Cliver, 1985). The first reported association of viruses with shellfish-borne gastroenteritis infection was observed in the winter of 1976-77 in the UK when cockles were epidemiologically linked to 33 incidents affecting nearly 800 people (Appleton and Pereira, 1977). SRSV particles, like those seen in outbreaks of winter vomiting disease, were observed by electron microscopy in a high proportion of patient faeces. Nevertheless, no shellfishborne outbreak ever had the magnitude of the one reported in Shanghai in 1988, caused by hairy clams (Halliday et al., 1991).

Bioaccumulation of viruses in the shellfish digestive tract is a very rapid phenomenon. Viruses are readily adsorbed to shellfish tissue within one-hour contact time and maximum virus levels may be observed after six hours (Abad et al., 1997). Adsorption of viruses on substrates such as feces, kaolinite, or unicellular algae, considerably increases shellfish accumulation efficiency (Metcalf et al., 1979).

Commercial heat treatment (cooking) is employed to reduce the levels of microbial contaminants in shellfish. Heat can render many viruses non infectious, however the degree of cooking required to reliably inactivate viruses would probably render oysters unpalatable to consumers (McDonnell et al., 1997). Laboratory studies show that enteric viruses and notably hepatitis A virus may be found in cooked shellfish (Abad et al., 1997). In addition, outbreaks of gastroenteritis and hepatitis have been linked to consumption of commercially cooked cockles or oysters (Appleton and Pereira, 1977; Kohn et al., 1995). High pressure treatment was shown efficient to inactivate HAV within oyster tissues, suggesting that this technology may be usefull for sporadically contaminated shellfish (Calci et al. 2005).

\section{Effects of viral contamination of molluscs on the international shellfish industry}

Most countries have endorsed sanitary controls on live bivalve shellfish. In the European Union, these are covered by Council Directive 91/492/EEC (Anonymous, 1991) and in the United States, by interstate trading agreements set out in the Federal Drug Administration National Shellfish Sanitation Program Manual of Operations (Anonymous, 1993). These regulations cover similar ground on the requirements, among others, for harvesting area classification, depuration, relaying, analytical methods, and provisions for suspension of harvesting from classified areas following a pollution or public health emergency. A major weakness of these controls is the use of traditional bacterial indicators of faecal contamination, such as the faecal coliforms or E. coli, to assess contamination and hence implement the appropriate control measures. Faecal indicators are either measured in the shellfish themselves (EU perspective) or in the shellfish growing waters (US FDA perspective). However, several reports describe a lack of correlation between bacterial indicator microorganisms and viruses, and pathogenic viruses may be detected in shellfish from areas classified as suitable for commercial exploitation according fecal coliform criteria (Abad et al., 1997; Lees, 2000; Le Guyader et al., 2000). The guidelines establish that shellfish meeting a microbiological standard of less than $230 \mathrm{E}$. coli or 300 faecal coliforms in $100 \mathrm{~g}$ of shellfish flesh can be placed on the market for human consumption. Human enteric viruses, e.g. norovirus, rotavirus and hepatitis A virus have been detected in shellfish which were adequate for public consumption according criteria based on the numbers of 
bacterial indicators (Jofre et al., 1993; Bosch et al., 1994; Le Guyader et al., 2000; Romalde et al., 2002). Additionally, hepatitis A and gastroenteritis outbreaks have been associated with the consumption of shellfish meeting legal standards (Bosch et al., 2001; Le Guyader et al., 1996; 2003; Lees, 2000; Mele et al., 1989, Boxman et al. 2006).

The legislation also requires that third country imports into the EU and US have to be produced to the same standard as domestic products. Exporting nations have therefore developed programs for compliance with the regulations of their target export markets. Nevertheless, a number of examples of trans-national outbreaks have recently been reported following trade between EU Member States (Christensen et al., 1998) and importation of shellfish from third countries into the EU and the US (Bosch et al., 2001; Sánchez et al., 2002; Kingsley and Richards, 2003).

European shellfish trade turnover represents $460 \mathrm{M} €$ per year, and increases by around 7 $\%$ each year. The European production represents more than a third of the worldwide shellfish production (i.e., in 1991, 180000 tons of live weight: $72 \%$ of farmed bivalves, 28 $\%$ wild - Eurostat data) and 8500 companies currently employ around 23000 workers. This activity is one of the major sources of employment in coastal areas (Ireland, France, Spain, The Netherlands).

Important trade exchanges of shellfish take place worldwide. For example in the European Community, France who is the main oyster producer (140 $000 \mathrm{t}$ /year) and consumer of the EC also exports oysters, mainly to Belgium, and imports oysters from Ireland and The Netherlands (about $1500 \mathrm{t}$ in 1994). Sixty percents of the 1.1 million t of mussels harvested in the world each year are produced by the EC, Spain being the second largest producer worldwide after China. France produces fewer mussels than it needs for its consumption: 20 to $40 \%$ of the mussels are imported from other countries (Spain, The Netherlands, United Kingdom).

Shellfish contamination has also an impact on the quality of life. Local population and tourists appreciate the nice quality of life in coastal areas. Coastal tourism has a high economic impact and major local implications, especially for employment. This tourism, if primarily interested by recreative activities, is also aware and concerned by the environment and landscape preservation. Shellfish harvesting activities, if well managed and regulated, could also contribute to better protect the environment. People would privilege these activities in areas where the water is of recognized quality and the environment most protected and closest to wilderness. Thus, a sustainable management of the aquaculture, would not only have direct and indirect incidences on employment (annexe trade activities: tourism employment, equipment, hotel, beach activities, rentals...) but also on the protection of rural and coastal development.

\section{Methods for detecting viruses in molluscan shellfish and associated problems}

Virus detection in shellfish has to overcome several difficulties. On the one hand, viruses are expected to be present in shellfish in very low numbers, which nevertheless are sufficient to pose a health risk. This low virus load implies the use of methodologies yielding a high efficiency of virus recovery from shellfish tissues. On the other hand, shellfish extracts are both highly cytotoxic and not adequate to be inoculated in cell cultures for the detection of culturable viruses, and not compatible either with polymerase chain reaction (PCR) based methodologies for the detection of non culturable viruses, particularly if a reverse transcription must be previously performed (RT-PCR). The key objective is then to develop procedures for shellfish analysis which result in a low volume of a non-cytotoxic or, even better nowadays, highly pure nucleic acid preparation with no inhibitory effect to the PCR. As a matter of fact, in this latter case, the degree of virus detection effectiveness achieved after RT-PCR is essentially the result of two related 
factors: the efficiency of recovery of the extraction procedure applied to the shellfish sample and the degree of final purity of the recovered virus.

Table 3 lists different procedures for the processing of shellfish samples prior to the specific virus detection by molecular procedures since the most relevant shellfishborne viral pathogens are non culturable. The first decision is to choose between performing virus detection in dissected shellfish tissues or in whole shellfish meats. Studies on the localization of human enteric viruses in shellfish tissues revealed that most of the virus could be found in the stomach and digestive diverticula (Abad et al., 1997; Romalde et al., 1994). Atmar and co-workers reasoned that removal of these organs for virus extraction might simplify and shorten the time needed to purify viral nucleic acid for RT-PCR but also improve the sensitivity by increasing the number of individuals analyzed (Atmar et al., 1996). Testing the stomach and digestive gland for virus detection presented several advantages in comparison with testing whole shellfish: less time-consuming procedure, increased test sensitivity, and decrease in the sample-associated interference with RTPCR.

Following virus extraction, a variety of subsequent nucleic acid extraction and purification protocols may be employed (Table 3). Due to the small size of the PCR reaction volumes, a reconcentration step is incorporated prior to the molecular assay. Nucleic acid purification based on virus lysis with guanidine and recovery with a silica matrix (Boom et al., 1990; Lees et al., 1994), or, alternatively, the use of organic solvents for purification, followed by nucleic acid precipitation using cetyltrimethyl ammonium bromide (CTAB) (Atmar et al., 1995; Jaykus et al., 1994), remain the procedures of choice. However, a wide variety of commercial kits have been applied for nucleic acid purification, offering reliability combined with convenience (Loisy et al., 2000; Schwab et al., 2000; Shieh et al.,, 1999).

Molecular analysis of viruses in environmental samples involves problems with inhibitors, low virus concentrations, and sequence variation. As the concentration-extraction procedure is not virus specific, the nucleic acid of several viruses can be extracted at the same time. RT-PCR must be performed under stringent conditions and confirmed by hybridization. Sometimes it is necessary to analyse the amplified sequence in order to characterise the viral strains. This is particularly important for norovirus detection, due to its wide strain diversity. However, sequence analysis is hampered by the sometimes scarce product obtained after PCR amplification from shellfish tissues. In addition, the high genetic diversity of norovirus makes it necessary to use broadly reactive primers. Despite several improvements in the methodology, up to now no single primer set is able to amplify all strains (Atmar and Estes, 2001; Vinje et al., 2003). In the absence of such a universal primer set, multiple sets need to be used to be able to detect all strains (Le Guyader 1996). The use of multiple primer sets enhances the chance to detect a greater number of strains, and the homology of the primers with the norovirus strain is important in terms of sensitivity (Le Guyader et al., 1996, Atmar and Estes 2001). No single assays stands out as the best by all criteria such as evaluation of sensitivity, detection limit, assay format for stool analysis and thus it is even more difficult for shellfish sample with very low contamination (Vinje et al 2003). For HAV, primer selection is easier since the degree of variation, particularly in the non-coding regions, is significantly lower (Costafreda et al., 2006).

Not too long ago, methods for the detection of viral pathogens were restricted to assays for culturable viruses, focused almost entirely on enteroviruses, and the BGM cell line has been for long time the choice for infectivity assays of enteroviruses in environmental samples (Bosch, 1998; Morris and Waite, 1980; Rao et al., 1986). Despite that enteroviruses do not appear as epidemiologically relevant environmental contaminants, it will remain important to gather data on their occurrence in the environment until the global eradication of poliomyelitis becomes a reality. However, even for this latter purpose, molecular tools provide better perspectives than cell culture techniques. Wild-type rotaviruses present difficulties in their in vitro replication, although most isolates may be adapted to grow in several cell lines such as the monkey kidney cell line MA104 or the 
human intestinal cell line CaCo-2 (Kitamoto et al., 1991). The standard methods for the diagnosis of specific infectious rotaviruses involve immunofluorescence tests and optical microscopic counting of infected foci in the culture (Bosch et al., 1988; Hejkal et al., 1984; Smith and Gerba, 1982). A further refinement in this direction was the use of flow cytometry for the detection of fluorescent foci in rotavirus infected cells (Abad et al., 1998). Flow cytometry is applicable for the detection of rotaviruses in environmental samples through an automatable and standardisable procedure, that is much less cumbersome than direct optical microscopy screening of cell cultures for fluorescent foci.

Another approach for the recovery of viruses that replicate poorly in cell cultures is to employ an integrated cell culture - reverse transcriptase-polymerase chain reaction system (CC-RT-PCR), enabling the in-vivo amplification of virus sequences in cell culture prior to their detection by PCR, thus accomplishing the dual purpose of increasing the number of copies of target nucleic acid and of incorporating an infectivity assay as well (Ma et al., 1994; Pintó et al., 1995). This approach has been reported for detection of infectious astrovirus (Abad et al., 1997) and enterovirus (Murrin and Slade, 1997; Reynolds et al., 1996). Whenever possible, the use of a combined cell culture-RT-PCR procedure that utilizes the major advantages of the separate methodologies, while overcoming many of their disadvantages is recommended. The inclusion of an infectivity test prior to the specific detection may contribute to solve the lack of sensitivity required for some type of samples such as environmental samples. However, so far the use of cell monolayers is of little use for the primary isolation of hepatitis A virus and unavailable for norovirus detection.

The requirement of sophisticated facilities and well-trained personnel to conduct studies with enteric viruses and the unreliability of bacterial model microorganisms led to the search for alternatives. Several bacteriophage groups appear as promising candidates, among them somatic coliphages (IAWPRC Study Group on Health Related Water Microbiology, 1991), F+ specific (male-specific), RNA (FRNA) bacteriophages (Havelaar, 1993) and Bacteroides fragilis bacteriophages (Tartera and Jofre, 1987), all of them with available ISO (International Standardization Office) procedures for their detection in water.

FRNA phages in particular have been described as promising candidates to evaluate the virological quality of shellfish (Lees, 2000). Several studies have shown a correlation between the elimination kinetics of F+ RNA phages and those of enteric viruses (Dore and Lees, 1995; Power and Collins, 1989; Power and Collins, 1990). Nevertheless reports on discrepancies in the occurrences of FRNA phages and pathogenic viruses are frequent. In shellfish associated with a large outbreak of hepatitis A reported in the East of Spain in 1999, with 184 serologically confirmed cases, the discrepancy observed between hepatitis A virus and FRNA phages was 55\%, while a 50\% discordance was ascertained between generic enteric virus occurrence and F+ presence (Bosch et al., 2003). In another study comparing the validity of E.coli, enterovirus and FRNA bacteriophages as indicator microorganisms, the phages failed to predict the risk of viral illness (Miossec et al., 2001). Additionally, when the comparative positivity for human enteric viruses and FRNA phages was investigated in 101 randomly chosen shellfish samples from South and West coast of France, a good correlation between the occurrence of enteric viruses and FRNA phages was observed in only $49 \%$ of the samples (Le Guyader, unpublished results).

Phages, that could be reliable indicators in some cases, can be used to classify area for sanitary safety, but it will not tell if a certain batch of shellfish is virus-contaminated, (Hernroth et al., 2002). In the same type of cold seawater, a correlation was found between noroviruses and phage contamination of mussels, but more than half of the norovirus-positive samples were negative for FRNA phages and a positive FRNA phage result was less than twice as common in samples with norovirus than in these without norovirus, raising the question to use FRNA as an indicator (Myrmel et a., 2004). A study conducted among different European countries showed geographic variations with shellfish collected from Southern Europe negative for FRNA contained human viruses (Formiga-Cruz et al., 2002). In Italy, most of shellfish found contaminated with hepatitis A virus did not present any phage or E. coli contamination (Croci et al. 2000). Recently a 
one-year study in the Netherlands showed the presence of phages in $67 \%$ of oyster samples analysed, but without the presence of pathogenic viruses such as norovirus or hepatitis A virus (Looder-Verschoor et al., 2005). Exhaustive studies are still required to ascertain the validity of a candidate indicator in a given scenario. In the end we should probably give up our hopes of finding a "universal" indicator for viruses, applicable to all situations, and resign ourselves to the use of particular indicator, index, or model microorganisms for specific purposes.

\section{Improving detection of molluscan shellfish virus contamination using new molecular based methods.}

The advent of molecular techniques for virus detection, and particularly RT-PCR, provided exquisite tools for the detection of fastidious health-significant viruses in food and environmental samples. Health-significant viruses, which were previously unrecognizable because they replicate poorly or not at all in cell cultures, became detectable with nucleic acid based techniques. Virologists initially employed hybridization assays which have been more recently replaced by polymerase chain reaction based procedures (Bosch et al., 1996; Jaykus et al., 1996; Jothikumar et al., 1995; Le Guyader et al., 1996; Lees et al., 1994; Pintó et al., 1996; Schwab et al., 1998; Villena et al., 2003).

Many potential users may find PCR cumbersome, since a single test entails many different manual steps, and will consider the technique as suitable only for academic or reference labs, and inadequate for routine monitoring. However, over the last decade, PCR technology improved on several fronts. On the one hand, commercial PCR systems significantly ameliorated convenience, and have been quickly adopted for diagnostic laboratories. Nevertheless, the most dramatic improvement comes from the emergence of combined rapid thermocycling and fluorescence monitoring of amplified product, collectively referred as "rapid-cycling real-time PCR" (Cockerill, III and Smith, 2002; Costafreda et al., 2006; Gassilloud et al., 2003; Kageyama et al., 2003; Loisy et al., 2005), together with nucleic acid sequence-based amplification or NASBA techniques (Jean et al., 2001; Yates et al., 2001), both of which now applicable in several commercially available systems. These procedures enable not only qualitative determination but also, and particularly, quantitative diagnostic assays. Although the generic determination of pathogens is the essence of diagnostic practices, the possibility to quantitatively detect virus agents represents a seminal refinement in routine monitoring virology.

As stated above, norovirus and hepatitis A virus are the two most significant virus targets in shellfish tissues, due to their incidence and pathogenicity. For this reason, considerable attention has been dedicated to the development of real-time procedures for the detection of these agents in bivalve molluscan shellfish (Costafreda et al., 2006; Jothikumar et al. 2005; Loisy et al., 2005; Nishida et al. 2003). However methods cited in the literature are diverse, complex, poorly standardised and restricted to a few specialist laboratories. It is obvious that quality control and quality assurance issues must be solved, as well as simplification and automation of molecular procedures before they could be adopted by routine monitoring laboratories. An additional difficulty to solve in the detection of viruses in molluscs is that traditional shellfish extraction procedures are not always compatible with RT-PCR detection: inhibitory substances are concentrated and recovered along with the viruses. A great variety of procedures have been developed for the removal of inhibitors, which include dialysis, solvent extraction, proteinase treatments, lyophilization, gel or glass filtration, nucleic acid adsorption or precipitation, antibody capture, and the use of commercial kits (Atmar et al., 1995; Jaykus et al., 1996; Loisy, et al., 2000; Schwab et al., 2000; Shieh et al., 1999; Tsai et al., 1993). The rule of thumb is that the degree of final purity of the assayed sample greatly determines the sensitivity of PCR, or particularly, RTPCR virus detection. 
Methodologies for the accurate quantification of norovirus and hepatitis A virus in shellfish samples are being developed. The general approach is based on the use of several controls to measure the efficiency of those critical steps for the quantification: the virus and nucleic acids extractions, and the RT-PCR reactions. The first purpose involves the use of a non-pathogenic virus of similar structural characteristics to those of the target virus. In the case of hepatitis A virus, since it belongs to the Picornaviridae family, another member of the same family is used to validate the behaviour of hepatitis A virus during its extraction from the shellfish tissue as well as during the nucleic acids extraction procedures (Costafreda et al., 2006). Encephalomiocarditis virus (EMCV) has been proposed as a model for hepatitis A virus in validation studies of hepatitis A virus removal in blood products manufacturing by several agencies such as the European Agency for the Evaluation of Medicinal products (http://www.emea.eu.int/pdfs/human/bwp/026995en.pdf) or the American Food and Drug Administration (http://www.fda.gov/cber/sba/igivbax042705S.pdf). However, the use of this virus is hampered by its potential pathogenicity in several animals, including primates (Citino et al., 1988) and even man (Kirkland et al., 1989). Mengo virus is serologically indistinguishable from EMCV, and non-pathogenic for man, although it may infect several animals. The removal of the poly-C tract from the $5^{\prime} \mathrm{NCR}$ of the wild-type Mengo virus, gives rise to a mutant strain, i.e. Mengo virus vMC0, with the same growth and structural properties but with no pathogenic capacity (Martin et al., 1989). Mengo virus vMC0 is employed as an extraction control for hepatitis A virus (Costafreda et al., 2006), since it represents a phenotypic variant of Mengo virus, avirulent in all animal species (murine and non-murine) so far tested, and used as a vaccine for a wide variety of hosts, including baboons, macaques and domestic pigs (Osorio et al., 1996). The same Mengo virus vMC0 is at the time of writing this chapter validated within the framework of an EU committee (CEN TAG4) as an extraction control, not only for hepatitis A virus but also for other viruses, such as norovirus, in shellfish, and other food matrices as fruits and salads.

It is well known that one limitation of molecular techniques is that they fail to discern between infectious and non-infectious particles which may be of critical relevance in environmental virology (Abad et al., 1994; Gassilloud et al., 2003). Several issues should however be taken in consideration. Most enteric viruses of public health concern bear RNA genomes. In studies employing RT-PCR, it has been shown that poliovirus genomic RNA is not stable in nonsterilized seawater (Tsai et al., 1995). While free DNA is fairly stable, it is unlikely that a free single-stranded RNA genome like those of noroviruses or hepatitis A virus would remain stable without its protein coat in the marine environment. This presumption is less clear for the double stranded RNA genome of rotaviruses.

A possible approach for the molecular recovery of infectious viruses is to employ an antibody capture RT-PCR. This has been applied to the detection of hepatitis A virus in seeded shellfish samples and shown to be both sensitive and useful to remove RT-PCR inhibitors as well (Deng et al., 1994; Graff et al., 1993; López-Sabater et al., 1997). Since recognition by a conformationally dependent monoclonal antibody is lost when the particle conformation is altered, coupling of the molecular procedure with capture with this type of antibody may enable to discern between intact and altered virions. This approach may prove useful for other enteric viruses, provided that adequate immunological reagents for the most relevant viral pathogens are available. For this purpose, recombinant virus-like particles, which can be obtained in very high numbers in in-vitro expression systems (Crawford et al., 1994; Lawton et al., 1997; Caballero et al., 2004), may be employed for the production of antibodies of non culturable viruses. Recent developments describe methods based on antigenic detection for norovirus (Tian and Mandrell 2006, Colquhoum et al. 2006) but the high diversity of norovirus may limit their specificity and sensitivity (Zheng et al. 2006). 


\section{Depuration of viral contaminants in molluscan shellfish}

Conventional commercial processes employed to purge out the microbial contamination of live bivalves are depuration, performed in tanks, and relaying, performed in the natural environment. Tank based depuration is now widely practiced in many European countries, while it is less widely used in the US (Otwell et al., 1991; Richards 1988). Depuration periods may vary from 1 to 7 days, since minimum time periods for depuration are not stipulated in the legislation, with around 2 days being probably the most widely used period.

Early studies, using artificially spiked soft shell clams, reported that most viruses were purged within a 24-48 hour period, and that low levels of viruses were depurated more rapidly than high levels (Metcalf et al., 1979). More recent studies show that although depuration and relaying procedures may be insufficient to completely remove viruses (Abad et al., 1997; De Medici et al. 2001; Kingsley and Richards, 2003; Loisy et al. 2005; Pommepuy 2003; Richards, 1988 Schwab et al. 1998), they do contribute to reduce virus levels and hence the risk of infection due to shellfish consumption (Bosch et al., 1994). Process temperature appears as an important factor for effective virus removal (Dore et al., 1998; Jaykus et al., 1994; Pommepuy et al. 2003; Power and Collins, 1990), although a raise in depuration temperature may result in increased shellfish mortality. Nevertheless, epidemiological evidence reveals that enteric viruses can be transmitted to man after consuming shellfish which has been depurated (Gill et al., 1983; Heller et al., 1986; Sockett et al., 1993, Cook and Ellender 1986, Heller et al. 1986). Once again compliance with bacterial end-product standards does not provide a guarantee of virus absence, and bacterial depuration rates can not accurately predict virus removal rates. Using rotavirus VLPs the long term persistence of the surrogate was demonstrated (Loisy et al. 2005). After several weeks in natural conditions, the surrogate was still detected suggesting that after contamination by human enteric viruses, shellfish may be unsafe for human consumption for quite a long period of time (Loisy et al. 2005). The finding of specific attachment of Norwalk virus or recombinant VLPs to shellfish digestive tissues and the capture of some particles by shellfish phagocytes may explain why depuration in oysters is not an effective mechanisms for eliminating virus (Le Guyader et al. 2006).

\section{Future trends in virus studies in shellfish}

The last two decades of virological research have contributed to significant progresses in the field of medical virology. These include the development of methodologies for the detection and characterization of non-culturable waterborne and foodborne viruses, the recognition of waterborne outbreaks caused by hepatitis $A$ and $E$ viruses, the consideration of rotavirus as the single most important cause of severe children gastroenteritis and norovirus as the most frequent agent of foodborne diarrhoea, the characterization of other important agents of non bacterial gastroenteritis such as astroviruses, sapoviruses, adenoviruses, and the assessment of the zoonotical transmission of some of the afore mentioned agents.

A poorly understood aspect in the epidemiology of several enteric viruses that requires further attention is the role of animal viruses in human disease. Nucleotide sequence analysis of some human enteric viruses has indicated a high degree of sequence similarity with animal strains. Notably, hepatitis $\mathrm{E}$ virus-related sequences have been detected in pigs (Banks et al., 2004; Meng, 2000; van der Poel et al., 2001;) and birds (Huang et al., 2002). Zoonotic infections may occur either through direct transmission, suspected for hepatitis E virus (HEV; Reyes, 1993) and caliciviruses (Humphrey et al., 1984), or through incidental co-infection of a host with animal and human viruses, resulting in the mixing of genes and generation of novel variants (recombination / reassortment; Unicomb et al., 1999). Recombination has been demonstrated as a mechanism for rapid expansion of 
diversity for noroviruses and rotaviruses, but it is likely to be a common feature of the RNA viruses involved (Jiang et al., 1999; Unicomb et al., 1999, Lopman et al. 2004). Viruses related to the human rotaviruses, astroviruses, noroviruses, sapoviruses, and HEV circulate in several animal species, providing a huge reservoir for virus diversity (Shirai et al., 1985; Meng et al., 1997; van der Poel et al., 2001; Huang et al., 2002, Oliver et al. 2006). To corroborate these hypothesis, animal viruses have been recently characterized in shellfish samples from the market either in Europe or in the US (Constantini et al. 2006; Dubois et al. 2004).

The severe acute respiratory syndrome" or SARS, reported In November 2002 (Ksiazek et al., 2003) is an example of an emerging disease. The primary mode of transmission of the SARS coronavirus appears to be direct mucous membrane contact with infectious respiratory droplets and/or through exposure to fomites. Several coronaviruses are known to spread by the fecal oral route, but there is no current evidence that this mode of transmission plays a key role in the transmission of SARS, although there is a considerable shedding of the virus in stools (Tsang, 2003). Another emerging pathogen of concern is the avian influenza H5N1 virus, highly pathogenic among birds and that in some cases has been transmitted from birds to humans. Most cases of H5N1 infection in humans to date have occurred as a result of direct contact with poultry or with surfaces and objects contaminated by their faeces. However, concern has recently been expressed about the potential for transmission of the virus to humans through water and sewage, although no definitive cases have been reported to date (WHO, 2006, http://www.who.int/water_sanitation_health/emerging/h5n1background.pdf).

Availability of quantitative and standardized virus methods will enable the future setting of legislative virus standards for bathing waters, bivalve shellfish and shellfish growing waters. Achievement of this objective will also enable the identification of key environmental factors, such as rainfall and sewage discharges, responsible for viral contamination in bathing and shellfish harvesting areas. Identification, and management, of such critical control points will provide an alternative approach to containing the virus risk and would permit the development of enhanced sanitary controls.

Finally, another long-time challenge in environmental virology is to conduct actual field studies to evaluate the environmental behaviour of human enteric viruses, which has to face the impossibility to introduce pathogens in the environment.

As model systems, recombinant tracers could be perfectly adequate for field studies of microbial tracking, since they may be produced in extremely high numbers (several milligram amounts). Additionally, their non-infectious nature makes them completely harmless and suitable to be used in scenarios where the use of actual viruses is hampered by the impossibility to introduce potential pathogens into, for instance, shellfish growing waters. Recombinant norovirus particles have been employed to investigate the behaviour of norovirus (Le Guyader et al., 2006; Redman et al., 1997) and rotavirus (Caballero et al., 2004; Loisy et al., 2004; 2005) in environmental samples.

8. Obviously, from the strictly structural point of view, there is no better surrogate of an actual virus pathogen to track their behavior in the environment than a non-infectious virus-like particle of the same virus. The demonstration of the capacity of Norwalk virus to bind to shellfish tissues at the same binding site as that used to human tissues suggests a possible coevolution mechanism involving the oyster as an intermediary vector (Le Guyader 2006). As knowledge increase in understanding the binding of human enteric viruses to human, more will be understand about their behaviour in shellfish. 


\section{References}

Abad, F.X., Pintó, R.M., and Bosch, A. 1998. Flow cytometry detection of infectious rotavirus in clinical and environmental samples. Appl. Environ. Microbiol. 64: 2392-2396.

Abad, F.X., Pintó, R.M., Diez, J.M., and Bosch, A. 1994. Disinfection of human enteric viruses in water by copper and silver in combination with low levels of chlorine. Appl. Environ. Microbiol. 60: 2377-2383.

Abad, F.X., Pintó, R.M., Villena, C., Gajardo, R., and Bosch, A., 1997, Astrovirus survival in drinking water, Appl. Environ. Microbiol. 63:3119-3122.

Anonymous. (1991). Council Directive of 15th July 1991 laying down the health conditions for the production and placing on the market of live bivalve molluscs

(91/492/EEC). Official Journal of the European Communities 268, 1-14.

Anonymous. (1993). National Shellfish Sanitation Program, Manual of Operations, 1993 Revision. US Department of Health and Human Services, Public Health Service, Food and Drug Administration.

Appleton, H., and Pereira, M.S., 1977, A possible virus aetiology in outbreaks of food poisoning from cockles, Lancet 1:780-781.

Atmar, R. L., and Estes M. K. 2001. Diagnosis of nonculturable gastroenteritis viruses, the human caliciviruses. Clin . Microbiol. Rev. 14:15-37.

Atmar, R.L., Neill, F.H., Romalde, J.L., Le Guyader, F., Woodley, C.M., Metcalf, T.G., and Estes, M.K. 1995. Detection of Norwalk virus and hepatitis A virus in shellfish with the PCR. Appl. Environ. Microbiol., 61: 3014-3018.

Atmar, R.L. Neill, F.H. ,Woodley, C.M. ,Manger, R., Fout, G.S. ,Burkhardt, W., Leja, L., McGovern, E. R., Le Guyader, F., Metcalf, T.G., and Estes M.K. 1996. Collaborative evaluation of a method for the detection of Norwalk virus in shellfish tissues by PCR. Appl. Environ. Microbiol. 62: 254-258.

Banks, M., Bendall, R., Grierson, S., Heath, G., Mitchell, J., and Dalton, H., 2004, Human and porcine hepatitis E virus strains, United Kingdom, Emerg. Infect. Dis. 10:953-955.

Blanton L.H., Adams S.M., Beard R.S., Wei G., Bulens S.N., Widdowson M-A., Glass R.I., Monroe S. 2006. Molecular and epidemiologic trends of caliciviruses associated with outbreaks of acute gastroenteritis in the United States, 2000-2004. J. Infect. Dis. 193: 413-421

Boom, R., Sol, C.J.A., Salimans, M.M.M., Jansen, C.L., Wertheim van Dillen, P.M.E., and Van der Noordaa, J. 1990. Rapid and simple method for purification of nucleic acids. J. Clin. Microbiol. 28: 495-503.

Bosch, A. 1998. Human enteric viruses in the water environment: a minireview. Int. Microbiol. 1: 191-196.

Bosch, A., Abad, F.X., Gajardo, R., and Pintó, R.M. 1994. Should shellfish be purified before public consumption? Lancet 344: 1024-1025. 
Bosch, A., Gajardo, R., Díez, J.M., and Pintó, R.M. 1996. Non isotopic automatable molecular procedures for the detection of enteroviruses. Mol. Cel. Probes 10: 81-89.

Bosch, A., Pintó, R.M., Blanch, A.R., and Jofre, J. 1988. Detection of human rotavirus in sewage through two concentration procedures. Wat. Res. 22: 343-348.

Bosch, A., Sánchez, G., Le Guyader, F., Vanaclocha, H., Haugarreau, L., and Pintó, R.M., 2001, Human enteric viruses in coquina clams associated with a large hepatitis $A$ outbreak, Water Sci. Tech. 43:61-66.

Bosch, A., Sánchez, G., Pintó, R.M., Abad, F.X., Pommepuy, M., and Le Guyader, F.S. 2003. Methods for virus detection in molluscs. Validation and standardization. In $A$. Villalba, B. Reguera, J.L. Romalde, R. Beiras (Eds.), Molluscan Shellfish Safety, (pp 333340). Santiago de Compostela: Consellería de Pesca e Assuntos Marítimos da Xunta de Galicia and Intergovernmental Oceanographic Commission of UNESCO.

Botero, L., Montiel, M., and Porto, L. 1996. Enteroviruses in shrimp harvested from contaminated marine waters. Int. J. Environ. Hlth Res. 6: 103-108.

Caballero, S., Abad, F.X., Loisy, F., Le Guyader, F.S., Cohen, J., Pintó, R.M., and Bosch, A., 2004, Rotavirus virus-like particles as surrogates in environmental persistence and inactivation studies, Appl. Environ. Microbiol. 70:3904-3909.

Cabelli, V., 1983, Public health and water quality significance of viral diseases transmitted by drinking water and recreational water, Water Sci. Technol. 15:1-15.

Calci, K.R., Meade, G.K., Tezloff, R.C., and Kinsgley D.H. 2005. High-pressure inactivation of hepatitis A virus within oysters. Appl. Environ. Microbiol. 71: 339-343.

Cheesbrough, J.S., Barkess-Jones, L., and Brown, D.W., 1997, Possible prolonged environmental survival of small round structured viruses, J. Hosp. Infect. 35:325-326.

Christensen, B.F., Lees, D., Wood, K.H., Bjergskov, T., and Green, J., 1998, Human enteric viruses in oysters causing a large outbreak of human food borne infection in 1996/97, J. Shellfish Res. 17:1633-1635.

Citino, S. B., B. L. Homer, J. H. Gaskin, and D. J. Wickham. 1988. Fatal encephalomyocarditis virus infection in a Sumatran orangutan (Pongo pygmaeus abelii). J. Zoo. Wildl. Med. 19: 214-218.

Cliver, D.O. 1985. Vehicular transmission of hepatitis A. Publ. Hlth Rev. 13: 235-292.

Cockerill, III, F.R., and Smith, T.F. 2002. Rapid-cycle real-time PCR: a revolution for clinical microbiology. ASM News 68: 77-83.

Colquhoum D.R., Schwab K.J., Cole R.N., Halden R.U. 2006. Detection of norovirus capsid protein in authentic standards and in stool extracts by matrix assisted laser desorption and nanospray mass spectrometry. Appl. Environ. Microbiol. 72 : 2749-2755.

Cook, D. W., and R. D. Ellender. 1986. Relaying to decrease the concentration of oysterassociated pathogens. J. Food Prot. 49:196-202.

Costafreda, M.I., Bosch, A. and Pintó, R.M. 2006. Development, evaluation and standardization of a real-time TaqMan reverse transcription-PCR assay for the 
quantification of hepatitis A virus in clinical and shellfish samples. Appl. Environ. Microbiol. 72: 3846-3855.

Costantini V., Loisy F., Joens L., Le Guyader F.S., Saif L.J. 2006. Human and animal enteric caliciviruses in oysters from different coastal regions of the United States. Appl. Environ. Microbiol. 72 : 1800-1809.

Crawford, S.E., Labbe, M., Cohen, J., Burroughs, M.H., Zhou, H.J., and Estes, M.K. 1994. Characterization of virus-like particles produced by the expression of rotavirus capsid proteins in insect cells. J. Virol. 68: 5945-5922.

Croci L., De Medici D., Scalfaro C., Fiore A., Divizia M., Donia D., Cosentino A.M., Moretti P., Costanti G. 2000. Determination of enteroviruses, hepatitis A virus, bacteriophages and Escherichia coli in adriatic sea mussels. J. Appl. Microbiol. 88 : 293-298.

Danovaro, R., Dell'anno, A., Trucco, A., Serresi, M., \& Vanucci, S. 2001. Determination of Virus Abundance in Marine Sediments. Appl. Environ. Microbiol. 67, 1384-1387.

De Medici, D., M. Ciccozzi, A. Fiore, S. Di Pasquale, A. Parlato, P. Ricci-Bitti, and L. Croci. 2001. Closed-circuit system for the depuration of mussels experimentally contaminated with hepatitis A virus. J. Food Prot. 64:877-880.

Deng, M.Y., Day, S.P., and Cliver, D.O. 1994. Detection of hepatitis A virus in environmental samples by antigen-capture PCR. Appl. Environ. Microbiol. 60: 1927-1933.

Dore, W.J., Henshilwood, K., \& Lees, D.N. 1998. The development of management strategies for control of virological quality in oysters. Wat. Sci. Tech. 38: 29-35.

Dore, W.J., and Lees, D.N. 1995. Behavior of Escherichia coli and male-specific bacteriophage in environmentally contaminated bivalve molluscs before and after depuration. Appl. Environ. Microbiol. 61: 2830-2834.

Dubois E., Merle G., Roquier C., Trompette A., Le Guyader F., Cruciere C., Chomel J-J. 2004. Diversity of enterovirus sequences detected in oysters by rt-heminested PCR. Int. J. Food Microbiol. 92 : 35-43.

Farthing, M.J.G., 1989, Viruses and the gut, Smith Kline \& French, Ltd, Welwyn Garden City.

Formiga-Cruz M., Tofino-Quesada G., Bofill_Mas S., Lees D.N., Henshilwood K., Allard A.K. et al. 2002. Distribution of human virus contamination in shellfish from different growing areas in Greece, Spain, Sweden, and the United-Kingdom. Appl. Environ. Microbiol. 68 : 5990-5998.

Fuhrman, J.A. 1999. Marine viruses and their biogeochemical and ecological effects. Lancet, 399: 541-548.

Gassilloud, B., Schwartzbrod, L., and Gantzer, B. 2003. Presence of Viral Genomes in Mineral Water: a Sufficient Condition To Assume Infectious Risk? Appl. Environ. Microbiol. 69: 3965-3969.

Gill, O.N., Cubitt, W.D., Mc. Wiggan, D.A., Watney, B.M., \& Bartlett, C.L.R. 1983. Epidemic of gastroenteritis caused by oysters contaminated with small round structured viruses. Brit. Med. J. 287: 1532-1534. 
Glass, R.I., Noel, J., Mitchell, D.K., Herrmann, J.E., Blacklow, N.R., Pickering, L.K., Dennehy, P., Ruiz-Palacios, G., de Guerrero, M.L., and Monroe, S.S. 1996. The changing epidemiology of astrovirus-associated gastroenteritis: a review. Arch. Virol. (Suppl), 12, 287-300.

Goh, K.T., Chan, L., Ding, J.L., and Oon C.J., 1984, An epidemic of cockles associated hepatitis A in Singapore, WHO Bull. 62:893-897.

Goyal, S.M. 1984. Viral pollution of the marine environment. Crit. Rev. Environ. Control 14: 1-32.

Graff, J., Ticehurst, J., and Flehmig, B. 1993. Detection of hepatitis A virus in sewage sludge by antigen capture polymerase chain reaction. Appl. Environ. Microbiol. 59: 31653170.

Halliday, M.L., Kang, L.-Y., Zhou, T.-Z., Hu, M.-D., Pan, Q.-C., Fu, T.-Y., Huang, Y.S., and Hu, S.L., 1991, An epidemic of hepatitis A attributable to the ingestion of raw clams in Shanghai, China, J. Infect. Dis. 164:852-859.

Havelaar, A.H. 1993. Bacteriophages as models of human enteric viruses in the environment. ASM News 59: 614-619.

Hejkal, T.W., and Gerba, C.P. 1981. Uptake and survival of enteric viruses in the blue crab, Gallinetes sapidus. Appl. Environ. Microbiol. 41: 207-211.

Heller, D., O. N. Gill, E. Raynham, T. Kirkland, P. M. Zadick, and R. Stanwell-Smith. 1986. An outbreak of gastrointestinal illness associated with consumption of raw depurated oysters. Brit. Med. J. 292: 1726-1727.

Hernroth B.E., Conden-Hansson A-C., Rehnstam-Holm A-S., Girones R., Allard A.K. 2002. Environmental factors influencing human viral pathogens and their potential indicator organisms in the blue mussel, Mytilus edulis: the first scandinavian report. Appl. Environ. Microbiol. 68 : 4523-4533.

Huang, F.F., Haqshenas, G., Shivaprasad, H.L., Guenette, D.K., Woolcock, P.R., Larsen, C.T., Pierson, F.W., Elvinger, F., Toth, T.E., and Meng, X.J., 2002, Heterogeneity and seroprevalence of a newly identified avian hepatitis $E$ virus from chickens in the United States, J. Clin. Microbiol. 40:4197-4202.

Humphrey, T.J., Cruickshank, J.G., and Cubitt, W.D., 1984, An outbreak of calicivirus associated gastroenteritis in an elderly persons home. A possible zoonosis? J. Hyg. (Lond) 93:293-299.

IAWPRC Study Group on Health Related Water Microbiology (A.H. Havelaar, Ed.). 1991. Bacteriophages as model viruses in water quality control. Wat. Res. 25: 529-545.

Jaykus, L.A., De Leon, R., and Sobsey, M.D. 1996. A virion concentration method for detection of human enteric viruses in oysters by PCR and oligoprobe hybridization. Appl. Environ. Microbiol. 62: 2074-2080.

Jaykus, L.A., Hemard, M.T., and Sobsey, M.D. 1994. Human Enteric Pathogenic Viruses. In C.R. Hackney and M.D. Pierson (Eds.), Environmental Indicators and Shellfish Safety (pp 92-153). New York: Chapman and Hall. 
Jean, J., Blais, B., Darveau, A., and Fliss, I. 2001. Detection of hepatitis A virus by the nucleic acid sequence-based amplification technique and comparison with reverse transcription-PCR. Appl. Environ. Microbiol. 67: 5593-5600.

Jiang, X., Espul, C., Zhong, W.M., Cuello, H., and Matson, D.O., 1999, Characterization of a novel human calicivirus that may be a naturally occurring recombinant, Arch. Virol. 144:2377-2387.

Jothikumar N., Lowther J.A., Henshilwwod K., Lees D.N., Hill V.R., Vinje J. 2005. Rapid and sensitive detection of noroviruses by using taqMan based one-step reverse transcription-PCR assays and application to naturally contaminated shellfish samples. Appl. Environ. Microbiol. 71 : 1870-1875.

Kageyama T., Kojima S., Shinohara M., Uchida K., FukushiS., Hoshino F.B., Takeda N., Katayama K. 2003. Broadly ractive and highly sensitive assay for Norwalk-like viruses based on real-time quantitative reverse transcription-PCR. J. Clin. Microbiol. 41 : 154-157.

Kingsley, D. H., and G.P. Richards. 2003. Persistence of hepatitis A virus in oysters. J. Food Prot. 66:331-334.

Kirkland, P. D., R. A. Hawkes, H. M. Naim, and C. R. Boughton. 1989. Human infection with encephalomyocarditis virus in New South Wales. Med. J. Austral. 151: 176.

Kitamoto, N.K., Ramig, R.F., Matson, D.O., and Estes, M.K. 1991. Comparative growth of different rotavirus strains in differentiated cells (MA104, HepG2 and CaCo-2). Virology 184: 729-737.

Kohn, M.A., Farley, T.A, Ando, T., Curtis, M., Wilson, S.A., Jin, Q., Monroe, S.S., Baron, R.C., McFarland, L.M., and Glass, R.I. 1995. An outbreak of Norwalk virus gastroenteritis associated with eating raw oysters. Implications for maintaining safe oyster beds [published erratum appears in J. Am. Med. Assoc. May 17; 273(19),1492, 1995] J. Am. Med. Assoc. 273. 466-471.

Koopman, J.S., Eckert, E.A., Greenberg, H.B., Strohm, B.C., Isaacson, R.E., and Monto, A.S., 1982, Norwalk virus enteric illness acquired by swimming exposure, Am.J. Epidemiol. 115:173-177.

Ksiazek, T.G., Erdman, D., Goldsmith, C.S., Zaki, S.R., Peret, T., Emery, S., Tong, S., Urbani, C., Comer, J. A., Lim, W., Rollin, P.E., Dowell, S.F., Ling, A.-E., Humphrey, C.D., Shieh, W.-J., Guarner, J., Paddock, C.D., Rota, P., Fields, B., DeRisi, J., Yang, J.-Y., Cox, N., Hughes, J.M., LeDuc, J.W., Bellini, W.J., Anderson, L.J., and the SARS Working Group, 2003, A novel coronavirus associated with severe acute respiratory syndrome, $\mathrm{N}$. Engl. J. Med. 348:1953-1966.

Lawton, J. A., Zeng, C.Q., Mukherjee, S.K., Cohen, J., Estes, M.K., and Prasad, B.V. 1997. Three-dimensional structural analysis of recombinant rotavirus-like particles with intact and amino-terminal-deleted VP2: implications for the architecture of the VP2 capsid layer. Journal of Virology 71: 7353-7360.

Lees, D.N. 2000. Viruses and bivalve shellfish. Int. J. Food Microbiol. 59, 81-116.

Lees, D.N., Henshilwood, K., and Dore, W.J. 1994. Development of a method for detection of enteroviruses in shellfish by PCR with poliovirus as a model. Appl. Environ. Microbiol. 60: 2999-3005. 
Le Guyader F., Estes M.K., Hardy M.E., Neill F.H., Green J., Brown D.W.G., Atmar R.L. 1996. Evaluation of a degenerate primer for the PCR detection of human caliciviruses. Arch. Virol. 141 : 2225-2235.

Le Guyader FS, Neill FH, Estes MK, Monroe SS, Ando T, Atmar RL. 1996. Detection and analysis of a small round structured virus strain in oysters implicated in an outbreak of acute gastroenteritis. Appl Environ Microbiol 62:4268-4272.

Le Guyader, F., L. Haugarreau, L. Miossec, E. Dubois, and M. Pommepuy. 2000. Threeyear study to assess human enteric viruses in shellfish. Appl. Environ. Microbiol. 66, 3241-4248.

Le Guyader, F. S., F. H. Neill, E. Dubois, F. Bon, F. Loisy, E. Kohli, M. Pommepuy, and R. L. Atmar. 2003. A semi-quantitative approach to estimate Norwalk-like virus contamination of oysters implicated in an outbreak. Int. J. Food Microbiol. 87:107-112.

Le Guyader, F. S., F. Loisy, R. L. Atmar, A. M. Hutson, M. K. Estes, N. Ruvoen-Clouet, M. Pommepuy, and J. Le Pendu. 2006. Norwalk virus specific binding to oyster digestive tissues. Emerg. Inf. Dis. 12:931-936.

Lewis, G.D., and Metcalf, T.G. 1988. Polyethylene glycol precipitation for recovery of pathogenic viruses, including hepatits $A$ virus and human rotavirus, from oysters, water and sediment samples. Appl. Environ. Microbiol. 54:1983-1988.

Linco, S.J., and Grohmann, G.S., 1980, The Darwin outbreak of oyster associated viral gastroenteritis, Med. J. Australia 1:211-213.

Lodder-Verschoor F., de Roda Husman AM., van der Bergf H.H.J.L. et al. 2005. Yearround screening of non commercial and commercial oysters for the presence of human pathogenic viruses. J. Food Prot. 68 : 1853-1859.

Loisy, F., R. L. Atmar, J. Cohen, A. Bosch, and F. S. Le Guyader. 2004. Rotavirus VLP 2/6: a new tool for tracking rotavirus in the marine environment. Res. Microbiol. 155:575578.

Loisy, F., Atmar, R. L. Guillon, P. Le Cann, P. Pommepuy, M. and Le Guyader, F. S. 2005. Real-time RT-PCR for norovirus screening in shellfish. J. Virol. Meth. 123:1-7.

Loisy, F., Le Cann, P., Pommepuy, M., and Le Guyader, F. 2000. An improved method for the detection of Norwalk-like caliciviruses in environmental samples. Lett. Appl. Microbiol. 31: 411-415.

Loisy F, Atmar RL, Le Saux J-C, Cohen J, Caprais M-P, Pommepuy M, Le Guyader FS. 2005. Rotavirus virus like particles as surrogates to evaluate virus persistence in shellfish. Appl Environ Microbiol. 71:6049-6053.

López-Sabater, E.I., Deng, M.Y., and Cliver, D.O. 1997. Magnetic immunoseparation PCR assay (MIPA) for detection of hepatitis A virus (HAV) in American oyster (Crassostrea virginica). Lett. Appl. Microbiol. 24: 101-104.

Lopman, B.A., Reacher, M.H., Van Duijnhoven, Y., Hanon, F.X., Brown, D., and Koopmans, M., 2003, Viral gastroenteritis outbreaks in Europe, 1995-2000, Emerg. Infect. Dis. 9:90-96. 
Lopman B, Vennema H, Kohli E, Pothier P, Sanchez A, Negredo A, Buesa J, Schreier E, Reacher M, Brown D, Gray J, Iturriza M, Gallimore C, Bottiger B, Hedlund KO, Torven M, von Bonsdorff CH, Maunula L, Poljsak-Prijatelj M, Zimsek J, Reuter G, Szucs G, Melegh B, Svennson L, van Duijnhoven Y, Koopmans M.. 2004. Increase in viral gastroenteritis outbreaks in Europe and epidemic spread of new norovirus variant. Lancet 363: 682-688.

Lu L., Li C., Hagedorn C.H. 2006. Phylogenetic analysis of global hepatitis E virus sequences: genetic diversity, subtypes and zoonosis. Rev. Med. Virol. 16 : 5-36.

Mackowiak, P.A., Caraway, C.T., and Portnoy, B.L. 1976. Oyster associated hepatitis : lessons from the Louisiana experience. Am. J. Epidemiol. 103, 181-191.

Martin, L. R., G. M. Duke, J. E. Osorio, D. J. Hall, and A. C. Palmenberg. 1996. Mutational analysis of the mengovirus poly $(\mathrm{C})$ tract and surrounding heteropolymeric sequences. $\mathrm{J}$. Virol. 70: 2027-2031.

McDonnell, S., Kirkland, K.B., Hlady, W.G., Aristeguieta, C., Hopkins, R.S., Monroe, S.S., and Glass, R.I. 1997. Failure of cooking to prevent shellfish-associated viral gastroenteritis. Arch. Inter. Med. 157, 111-116.

Mendez, I.,Hermann, L., Hazelton, P., Coombs, K. 2000. A comparative analysis of Freon substitutes in the purification of reovirus and calicivirus.

J. Virol. Meth. 90: 59-67.

Meng X.J., 2000. Novel strains of hepatitis E virus identifed from humans and other animal species: is hepatitis E a zoonosis? J. Hepat. $33: 842-845$.

Meng, X.J., Purcell, R.H., Halbur, P.G., Lehman, J.R., Webb, D.M., Tsareva, T.S., Haynes, J.S., Thacker, B.J., and Emerson S.U., 1997, A novel virus in swine is closely related to the human hepatitis E virus, Proc. Natl. Acad. Sci. USA 94:9860-9865.

Metcalf, T.G., Mullin, B., Eckerson, D., Moulton, E., and Larkin, E.P. 1979. Bioaccumulation and depuration of enteroviruses by the soft shelled clam, Mya arenaria. Appl. Environ. Microbio. 38: 275-282.

Miossec, L., Le Guyader, F., Pelletier, D., Haugarreau, L., Caprais, M-P., and Pommepuy, M. 2001. Validity of Escherichia coli, enterovirus and F-specific RNA bacteriophages as indicators of viral shellfish contamination. J. Shellfish Res. 20: 1223-1227.

Moore, A.C., Herwaldt, B.L., Craun, G.F., Calderon, R.L., Highsmith, A.K., and Juranek, D.D., 1994, Waterborne disease in the United States, 1991 and 1992, J. Am. Water Works Assoc. 86:87-99.

Morse, D.L., Guzewich, J.J., Hanrahan, J.P., Stricof, R., Shayegani, M., Deibel, R., Grabau, J.C., Nowak, N.A., Herrmann, J.E., Cukor, G., and Blacklow, N.R., 1986, Widespread outbreaks of clam- and oyster-associated gastroenteritis:Role of Norwalk virus. New Engl. J. Med. 314: 678-681.

Murphy, A.M., Grohmann, G.S., Christopher, R.J., Lopez, W.A., Davey, G.R., and Millsom, R.H., 1979, An Australia-wide outbreak of gastroenteritis from oysters caused by Norwalk virus, Med. J. Australia 2:329-333.

Myrmel M., Berg E.M.M., Rimstad E., Grinde B. 2004. Detection of enteric viruses in shellfish from the Norwegian coast. Appl. Environ. Microbiol. 70 : 2678-2684. 
Nishida, T., H. Kimura, M. Saitoh, M. Shinohora, M. Kato, S. Fukuda, T. Munemura, T. Mikami, T. Kawamoto, M. Akiyama, Y. Kato, K. Nishi, K. Kozawa, and O. Nishio. 2003. Detection, quantitation, and phylogenetic analysis of noroviruses in japanese oysters. Appl. Environ. Microbiol. 69:5782-5786.

Oh, D.-Y., Gaedicke, G., and Schreir, J.M. 2003. Viral agents of acute gastroenteritis in German children: Prevalence and molecular diversity. Journal of Medical Virology, 71, 8293

Oliver S.L., Batten C.A., Deng Y., Elschner M., Otto P., Charpilienne A; Clarke I.N., Bridger J.C., Lambden P.R. 2006. Genotype 1 and genotype 2 bovine noroviruses are antigenically distinct but share a cross reactive epitope with human noroviruses. J . Clin. Microbiol. 44 : 992-998.

O'Mahony, M., Gooch, C.D., Smyth, D.A., Thrussell, A.J., Bartlett, C.L.R., and Noah, N.D., 1983, Epidemic hepatitis A from cockles. Lancet, l:518-520.

Osorio, J. E., G. B. Hubbard, K. F. Soike, M. Girard, S. van der Werf, J. C. Moulin, and A. C. Palmenberg. 1996. Protection of non-murine mammals against encephalomyocarditis virus using a genetically engineered Mengo virus. Vaccine 14: 155-161.

Otwell, W.S., Rodrick, G.E., Martin, R.E (Eds.). 1991. Molluscan Shellfish Depuration. Boca Raton: CRC Press.

Parashar, U.D., Holman, R.C. Clarke, M.J. Bresee, J.S., and Glass R.I. 1998. Hospitalizations associated with rotavirus diarrhea in the United States, 1993 through 1995: surveillance based on the new ICD-9-CM rotavirus-specific diagnostic code. J. Infec. Dis. $177,13-17$.

Pintó, R.M., Abad, F.X. Gajardo, R., and Bosch, A. 1996. Detection of infectious astroviruses in water. Appl. Environ. Microbiol. 62: 1811-1813.

Pintó, R.M., Alegre, D., Dominguez, A., El-Senousy, W.M., Sánchez, G., Villena, C., Costafreda, M.I., Aragonès, L. and Bosch, A. 2006. Epidemiology of hepatitis A virus in urban sewage from two Mediterranean countries. Epidemiol. Infec. (In Press).

Pintó, R.M., Gajardo, R., Abad, F.X., and Bosch, A., 1995, Detection of fastidious infectious enteric viruses in water, Environ. Sci. Tech. 29:2636-2638.

Pommepuy, M., M-P. Caprais, J-C. Le Saux, C. Le Mennec, S. Parnaudeau, Y. Madec, M. Monnier, G. Brest, and F. S. Le Guyader. 2003. Evaluation of viral shellfish depuration in a semi-professional size tank, p 485-499. In A. Villalba, B. Reguera, J. L. Romalde, R. Beiras, (ed.), Molluscan Shellfish Safety, Conseilleria de Pesca e Assuntos maritimos da Xunta de Galicia and Intergovernmental Oceanographic Commission of UNESCO,Santiago de Compostela (Spain).

Pommepuy, M., D. Hervio-Heath , M-P. Caprais, M. Gourmelon , and F.S. Le Guyader. 2005. Fecal contamination in coastal area: an engineering approach. In Oceans and Health: Pathogens in the marine environment (S. Belkin Eds) Kluwer academic/Plenum Publishers, USA, pp. 331-360.

Power, U.F., and Collins, J.K. 1989. Differential depuration of poliovirus Escherichia-coli and a coliphage by the common mussel Mytilus-edulis. Appl. Environ. Microbiol. 55: 13861390. 
Power, U.F., and Collins, J.K. 1990. Elimination of coliphages and Escherichia coli from mussels during depuration under varying conditions of temperature salinity and food availability. J. Food Prot. 53, 208-212, 226.

Rao, V.C., and Melnick, J.L., 1986, Environmental Virology, In Aspects of Microbiology 13 (J.A. Cole, C.J. Knowles, D. Schlessinger, eds.), American Society for Microbiology, Washington, D.C.

Rao, V.C., Metcalf, T.G., and Melnick, J.L. 1986. Human viruses in sediments, sludges, and soils. Bull. WHO 64: 1-13.

Redman, J.A., Grant, S.B., Olson, T.M., Hardy, M.E., and Estes, M.K., 1997, Filtration of recombinant Norwalk Virus particles and bacteriophage MS2 in quartz sand:Importance of electrostatic interactions, Environ. Sci. Tech. 31:3378-3383.

Reyes, G.R., 1993, Hepatitis E virus (HEV):molecular biology and emerging epidemiology, Prog. Liver Dis. 11:203-213.

Reynolds, K.A., Gerba, C.P., and Pepper, I.L. 1996. Detection of infectious enteroviruses by an integrated cell culture-PCR procedure. Appl. Environ. Microbiol. , 62, 1424-1427.

Richards, G.P., 1985, Outbreaks of shellfish-associated enteric illness in the United-States :requisite for development of viral guidelines. J. Food Prot. 48:815-823.

Richards, G. P. 1988. Microbial purification of shellfish : a review of depuration and relaying. J. Food Protect. 51:218-251.

Romalde, J.L., Area, E., Sánchez, G., Ribao, C., Torrado, I., Abad, F.X., Pintó, R.M., Barja, J.L., and Bosch, A. 2002. Prevalence of enterovirus and hepatitis A virus in bivalve mollusks from Galicia (NW Spain): inadequacy of the EU standards of microbiological quality. Int. J. Food Microbiol. 74: 119-130.

Romalde, J.L., Estes, M.K., Szucs, G., Atmar, R.L., Woodley C.M., and Metcalf, T.G. 1994. In situ detection of hepatitis A virus in cell cultures and shellfish tissues. Appl. Environ. Microbiol. 60: 1921-1926.

Sánchez, G., Pintó, R.M., Vanaclocha, H. and Bosch, A. 2002. Molecular characterization of hepatitis A virus isolates from a transcontinental shellfishborne outbreak. J. Clin. Microbiol. 40: 4148-4155.

Schlauder, G.G., \& Mushahwar, I.K. 2001. Genetic heterogeneity of hepatitis E virus. J. Med. Virol. 65, 282-292.

Schwab, K. J., F. H. Neill, M. K. Estes, T. G. Metcalf, and R. L. Atmar. 1998. Distribution of Norwalk virus within shellfish following bioaccumulation and subsequent depuration by detection using RT-PCR. J. Food Prot. 61: 1674-1680.

Schwab, K.J., Neill,F.H., Fankhauser, R.L., Daniels, N.A., Monroe, S.S., Bergmire-Sweat, D.A., Estes, M.K., and Atmar, R.L. 2000. Development of Methods To Detect "NorwalkLike Viruses" (NLVs) and Hepatitis A Virus in Delicatessen Foods: Application to a FoodBorne NLV Outbreak. Appl. Environ.Microbiol. 66: 213-218.

Shieh, C.Y.-S. Calci, K.R., and Baric, R.S. 1999. A Method to detect low levels of enteric viruses in contaminated oysters. Appl. Environ. Microbiol. 65: 4709-4714. 
Shirai, J., Shimizu, M., and Fukusho, A., 1985, Coronavirus-, calicivirus-, and astroviruslike particles associated with acute porcine gastroenteritis. Nippon Juigaku Zasshi 47:1023-1026.

Smith, E.M., and Gerba, C.P. 1982. Development of a method for detection of human rotavirus in water and sewage. Appl. Environ. Microbiol. 43: 1440-1450.

Sobsey, M.D., Carrick, R.J., and Jensen, H.R. 1978. Improved methods for detecting enteric viruses in oysters. Appl. Environ. Microbiol. 36: 121-128.

Sockett, P.N., Cowden, J.M., LeBaigue, S., Ross, D., Adak, G., and Evans, H. 1993. Foodborne disease surveillance in England and Wales: 1989-1991. Com. Dis. Rep. 3: 159174.

Tartera, C., and Jofre, J. 1987. Bacteriophages active against Bacteroides fragilis in sewage-polluted waters. Appl. Environ. Microbiol. 53: 1632-1637.

Tian P., Mandrell R.2006. Detection of norovirus capsid proteins in faecal and food samples by a real-time immuno-PCR method. J. Appl. Microbiol. 100 : 564-574.

Tsai, Y.L., Sobsey, M.D., Sangermano, L.R., and Palmer, C.J. 1993. Simple method of concentrating enteroviruses and hepatitis $A$ virus from sewage and ocean water for rapid detection by reverse transcriptase-polymerase chain reaction. Appl. Environ. Microbiol. 59: 3488-3491.

Tsai, Y.-L., Tran, B., and Palmer, C.J. 1995. Analysis of viral RNA persistence in seawater by reverse transcriptase-PCR. Appl. Environ. Microbiol. 61: 363-366.

Tsang, T., 2003, Environmental issues. WHO Global Conference on Severe Acute Respiratory Syndrome (SARS), Kuala Lumpur, Malaysia, 17 - 18 June 2003.

Unicomb, L.E., Podder, G., Gentsch, J.R., Woods P.A., Hasan, K.Z., Faruque, A.S., Albert, M.J., and Glass, R.I., 1999, Evidence of high-frequency genomic reassortment of group A rotavirus strains in Bangladesh:emergence of type G9 in 1995, J. Clin. Microbiol. 37:18851891.

van der Poel, W.H.M., Verschoor, F., van der Heide, R., Herrera, M.I., Vivo, A., Kooreman M., and de Roda Husman, A.M., 2001, Hepatitis E Virus Sequences in Swine Related to Sequences in Humans, the Netherlands, Emerg. Infect. Dis. 6:970-976.

Villena, C., Morsy El-Senousy, W., Abad, F.X., Pintó, R.M., and Bosch, A. 2003. Group A rotavirus in sewage samples from Barcelona and Cairo: emergence of unusual genotypes. Appl. Environ. Microbiol. 69: 3919-3923.

Vinje, J., H. Vennema, L. Maunula, C-H. von Bonsdorff, M. Hoehne, E. Shreier, A. Richards, J. Green, D. Brown, S. Beard, S. Monroe, E. De Bruin, L. Svensson, M. P. G. Koopmans. 2003. International collaborative study to compare reverse transcriptase PCR assays for detection and genotyping of noroviruses. J. Clin. Microbiol. 41:4023-4033.

Williams, R.A., and Zorn, D.J. 1997. Hazard analysis and critical control point systems applied to public health risks: the example of seafood. Rev. Scientif. Tech. 16: 349-358.

Zheng D-P, Ando T., Fankhauser R.L., Beard R.S., Glass R., Monroe S.S 2006. Norovirus classification and proposed strain nomenclature. Virology. $346: 312-323$. 
Yates, S., Penning, M., Goudsmit, J., Frantzen, I., Van der Weijer, B., Van Strijp, D., and Van Gemen, B. 2001. Quantitative detection of hepatitis B virus DNA by real-time nucleic acid sequence-based amplification with molecular beacon detection. J. Clin. Microbiol. 39: 3656-3665. 
Table 1. Human enteric viruses with potential environmental transmission.

\begin{tabular}{|c|c|c|}
\hline Genus & Popular name & Disease caused \\
\hline \multirow[t]{3}{*}{ Enterovirus } & Polio & Paralysis, meningitis, fever \\
\hline & Coxsackie A, B & $\begin{array}{l}\text { Herpangina, meningitis, fever, } \\
\text { disease, respiratory } \\
\text { myocarditis, heart anomalies, rash, pleurodynia, } \\
\text { diabetes? }\end{array}$ \\
\hline & Echo & $\begin{array}{l}\text { Meningitis, fever, respiratory disease, rash, } \\
\text { gastroenteritis }\end{array}$ \\
\hline Kobuvirus & Aichi & Gatroenteritis \\
\hline Hepatovirus & Hepatitis A & Hepatitis \\
\hline Reovirus & Human reovirus & Unknown \\
\hline Rotavirus & Human rotavirus & Gastroenteritis \\
\hline Norovirus & Norwalk-like virus & Gastroenteritis \\
\hline Sapovirus & Sapporo-like virus & Gastroenteritis \\
\hline Hepevirus & Hepatitis E & Hepatitis \\
\hline $\begin{array}{l}\text { 9. Mamastrovir } \\
\text { us }\end{array}$ & Human astrovirus & Gastroenteritis \\
\hline Parvovirus & Human parvovirus & Gastroenteritis \\
\hline Coronavirus & Human coronavirus & Gastroenteritis, respiratory disease \\
\hline Torovirus & Human torovirus & Gastroenteritis \\
\hline Mastadenovirus & Human adenovirus & Gastroenteritis, respiratory disease, conjunctivitis \\
\hline Polyomavirus & $\begin{array}{l}\mathrm{JCV} \\
\mathrm{KV}\end{array}$ & $\begin{array}{l}\text { Progressive multifocal leukoencephalopathy } \\
\text { Nephropathy }\end{array}$ \\
\hline
\end{tabular}


Table 2. Examples of reported large (over 100 cases) virus outbreaks linked to shellfish consumption.

\begin{tabular}{|c|c|c|c|c|c|}
\hline Year & Country & $\begin{array}{l}\text { 10. Shell } \\
\text { fish }\end{array}$ & $\begin{array}{l}\text { No. of } \\
\text { Cases }\end{array}$ & Agent & Reference \\
\hline 1973 & $\overline{U S}$ & Oysters & 265 & $\mathrm{HAV}^{*}$ & $\begin{array}{l}\text { Mackowiak et } \\
\text { al., } 1976\end{array}$ \\
\hline 1976-77 & $\begin{array}{l}\text { Great } \\
\text { Britain }\end{array}$ & Clams & 800 & $\mathrm{SRSV}^{\dagger}$ & $\begin{array}{l}\text { Appleton, and } \\
\text { Pereira, } 1977\end{array}$ \\
\hline 1978 & Australia & Oysters & 2000 & $\mathrm{NoV}^{\ddagger}$ & $\begin{array}{l}\text { Murphy et al., } \\
1979\end{array}$ \\
\hline 1978 & Australia & Oysters & 150 & NoV & $\begin{array}{l}\text { Linco and } \\
\text { Grohmann, } \\
1980\end{array}$ \\
\hline $1980-81$ & $\begin{array}{l}\text { Great } \\
\text { Britain }\end{array}$ & Cockles & 424 & NoV & $\begin{array}{l}\text { O'Mahony et } \\
\text { al., } 1983\end{array}$ \\
\hline 1982 & US & Oysters & 472 & NoV & Richards, 1985 \\
\hline 1983 & $\begin{array}{l}\text { Great } \\
\text { Britain }\end{array}$ & Oysters & 181 & SRSV & Gill et al., 1983 \\
\hline 1983 & Malaysia & Cockles & 322 & HAV & $\begin{array}{l}\text { Goh, et a., } \\
1984\end{array}$ \\
\hline 1986 & US & $\begin{array}{l}\text { Clams } \\
\text { Oysters }\end{array}$ & $\begin{array}{l}813 \\
204\end{array}$ & NoV & $\begin{array}{l}\text { Morse et al., } \\
1986\end{array}$ \\
\hline 1988 & Shanghai & Clams & 292301 & HAV & $\begin{array}{l}\text { Halliday et al., } \\
1991\end{array}$ \\
\hline 1999 & Spain & Clams & 183 & HAV & $\begin{array}{l}\text { Bosch et al., } \\
2001\end{array}$ \\
\hline
\end{tabular}

* HAV: Hepatitis A Virus 
${ }^{\dagger}$ SRSV:Small round structured viruses

${ }^{\ddagger}$ NoV: Norovirus 
Table 3. Procedures for processing of shellfish samples prior to virus detection by RTPCR

\begin{tabular}{|c|c|c|}
\hline Process & Method & 11. Reference \\
\hline \multirow[t]{3}{*}{ Virus extraction } & Chloroform-butanol / cat-floc elution & Atmar et al., 1996 \\
\hline & Vertrel extraction & Mendez et al., 2000 \\
\hline & Proteinase $\mathrm{K}$ treatment & Jothikumar et al., 2005 \\
\hline \multirow[t]{4}{*}{ Virus concentration } & Organic flocculation & Sobsey et al., 1978 \\
\hline & Centrifugation & Sobsey et al., 1978 \\
\hline & Ultracentrifugation & Loisy et al., 2000 \\
\hline & PEG precipitation & $\begin{array}{l}\text { Lewis, and Metcalf } \\
\text { (1988); Atmar et al., } \\
1995\end{array}$ \\
\hline \multirow[t]{3}{*}{ RNA extraction } & Guanidium thiocyanate & $\begin{array}{l}\text { Boom et al., 1990; } \\
\text { Lees et al., } 1994\end{array}$ \\
\hline & $\begin{array}{l}\text { Cetyltrimethyl ammonium bromide } \\
\text { (CTAB) }\end{array}$ & $\begin{array}{l}\text { Atmar et al., 1995; } \\
\text { Jaykus et al., } 1994\end{array}$ \\
\hline & Commercial nucleic acid extraction kits & $\begin{array}{l}\text { Loisy et al., 2000; } \\
\text { Schwab et al., 2000; } \\
\text { Shieh et al., } 1999\end{array}$ \\
\hline
\end{tabular}

